\title{
The search for a more human face for Nelson Mandela: An urgent task
}

\begin{tabular}{|c|c|}
\hline $\begin{array}{l}\text { Author: } \\
\text { Tinyiko Malule }\end{array}$ & \\
\hline $\begin{array}{l}\text { Affiliation: } \\
{ }^{1} \text { Faculty of The } \\
\text { University of } \\
\text { South Africa }\end{array}$ & $\begin{array}{l}\text { ology, } \\
\text { retoria, }\end{array}$ \\
\hline $\begin{array}{l}\text { Note: } \\
\text { Tinyiko Malule } \\
\text { professor of th } \\
\text { the Faculty of } \\
\text { University of P } \\
\text { also assistant } \\
\text { and Vice Chan } \\
\text { University of F } \\
\text { the developm } \\
\text { university's Af }\end{array}$ & $\begin{array}{l}\text { ke is a } \\
\text { eology at } \\
\text { Theology, } \\
\text { retoria. He is } \\
\text { o the Principal } \\
\text { cellor of the } \\
\text { retoria in } \\
\text { ent of the } \\
\text { ica Strategy. }\end{array}$ \\
\hline $\begin{array}{l}\text { Corresponden } \\
\text { Tinyiko Malule }\end{array}$ & $\begin{array}{l}\text { ce to: } \\
\text { ke }\end{array}$ \\
\hline $\begin{array}{l}\text { Email: } \\
\text { tinyiko.malule } \\
\text { xihosana@yar }\end{array}$ & $\begin{array}{l}\text { «e@up.ac.za } \\
\text { oo.co.uk }\end{array}$ \\
\hline $\begin{array}{l}\text { Postal addres } \\
\text { Private Bag X2 } \\
0028 \text {, South A }\end{array}$ & $\begin{array}{l}\text { 0, Hatfield } \\
\text { rica }\end{array}$ \\
\hline $\begin{array}{l}\text { Dates: } \\
\text { Received: } 18 \\
\text { Accepted: } 14 \\
\text { Published: } 28\end{array}$ & $\begin{array}{l}\text { Aar. } 2015 \\
\text { May } 2015 \\
\text { Aug. } 2015\end{array}$ \\
\hline $\begin{array}{l}\text { How to cite th } \\
\text { Maluleke, T., } 2 \\
\text { search for a m } \\
\text { face for Nelso } \\
\text { urgent task', H } \\
\text { Studies/Theol } \\
71(3), \text { Art. \#29 } \\
\text { http://dx.doi. } \\
\text { hts.v71i3.2941 }\end{array}$ & $\begin{array}{l}\text { is article: } \\
015, \text { 'The } \\
\text { ore human } \\
\text { Mandela: An } \\
\text { TS Teologiese } \\
\text { gical Studies } \\
41,7 \text { pages. } \\
\text { rg/10.4102/ }\end{array}$ \\
\hline $\begin{array}{l}\text { Copyright: } \\
\text { C 2015. The A } \\
\text { Licensee: AOS } \\
\text { OpenJournals } \\
\text { licensed unde } \\
\text { Commons Attr } \\
\text { License. }\end{array}$ & $\begin{array}{l}\text { uthors. } \\
\text { S } \\
\text { This work is } \\
\text { the Creative } \\
\text { ibution }\end{array}$ \\
\hline Read online: & \\
\hline 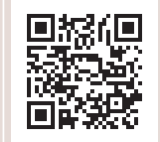 & $\begin{array}{l}\text { Scan this QR } \\
\text { code with your } \\
\text { smart phone or } \\
\text { mobile device } \\
\text { to read online. }\end{array}$ \\
\hline
\end{tabular}

For many reasons, reflecting on the life of Nelson Mandela is a precarious exercise. If Mandela is a symbol of the resilience of the human spirit under trying conditions, he is also a symbol that is appropriated in various ways - helpful and unhelpful - by various people. This article explores some of the unhelpful ways in which the name and person of Nelson Mandela is invoked. In particular, the article looks at the hagiographical orientation of several reflections on Mandela, cautioning how some of these may have an effect less noble than originally intended. Accordingly, the article asks: How much can the symbol of Mandela bear? How much more can Mandela give? The logic and rationale of Mandela hagiography is explored. Following his death, there has been an explosion of interest in the life and symbol that is Nelson Mandela. Mandela literature, including multi-media, is on the rise. If the symbol of Mandela is in danger of being 'cannibalised', there is also a danger of relegating Mandela to an ahistorical mythical figure. The solution lies in at least two area, namely, the increment of alternative Mandela narratives and the introduction of more critical Mandela narratives. In this regard, Mandela's own self-understanding as captured in his reflections about his life offer several clues which are explored in this article.

\section{Introduction}

Publications on the life and work of Nelson Mandela appear to be increasing, especially since his death in December 2013. The central question of the article is the following: Amongst the many faces, most of them hagiographical and romantic, how and where can we find the most human face of Nelson Mandela? As well as highlighting the danger of hagiography and character romanticisation, this article analyses the various ways in and purposes to which the name, person and symbol of Nelson Mandela are invoked and evoked by individuals and groups in South Africa and elsewhere. In particular, the reasons for and the dangers of the emerging single narrative of Mandela as a saint and a giant - an image that seems to reduce the stature of his comrades and the rest of humanity - are probed. The article proposes the increment of alternative Mandela narratives, and interpretations will assist in challenging the hegemony of the powerful single narrative that reigns. It also suggests and ventures a more critical, but not negative approach to Mandela. Using Nelson Mandela's own self-imaging, the article proposes themes and caveats through which the hegemonic and single-narrative of the Mandela personality can be shifted:

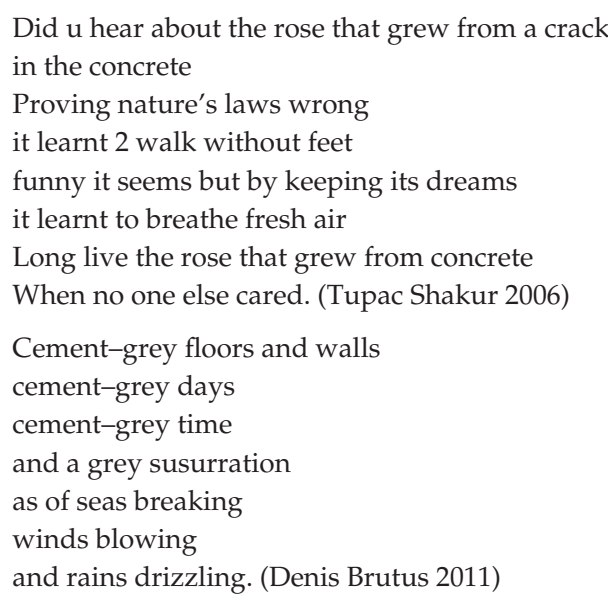

\section{What will be Left of Mandela?}

If Mandela is a symbol of what it means to be human (West 2004), he is also a symbol appropriated '... for myriad pursuits, hopes, frustrations, ambitions, visionary projections and 
mundane preoccupations' (Soyinka 2004). Soyinka (1988) captures this reality even better in a poem written before Mandela's release from prison:

Your bounty threatens me, Mandela that taut

Drumskin of your heart on which our millions

Dance. I fear we latch, fat leeches

On your veins. Our daily imprecations

Dull keen edges of your will

Compromises deplete your act's repletion -

Feeding will-voided stomachs of a continent,

What will be left of you, Mandela?

The questions Soyinka seems to be asking include the following: How much can the symbol of Mandela bear, and how much more can Mandela give? Following his death, there has been an explosion of interest in the life and symbol that is Nelson Mandela. Mandela literature, including multimedia, has been on the rise for some time. At least two motion films and several documentaries have been released. Earlier on, an audio book was published, containing Nelson Mandela's favourite African folktales, apparently chosen by Mandela himself, introduced by none other than Desmond Tutu and read out by celebrities from all over the world (Mandela 2002).

Recently, the South African Broadcasting Corporation has published a set of DVDs capturing the funeral proceedings for the burial of Nelson Mandela. More films may follow. The International Mandela Day fixed on his birthday in July has become a day of much attention-seeking jostling of the kind that Soyinka 'fears' in his poem. If the symbol of Mandela is in danger of being cannibalized, there is also a danger of making Mandela '... some kind of icon on a pedestal belonging to a museum' (West 2004:13).

One of the most common ways in which we 'bury' Mandela is through the 'praise' prism of iconology. Mandela is variously described as the icon of struggle, the reconciler, the 'last hero' (Sampson 1999:xxviii) of the 20th century, indeed, '... the last pure hero on the planet' (Stengel 2010:3). In his recent book, Schechter (2013) provides an astonishing amount of superlative adjectives and nouns to describe Mandela. They include athlete, diplomat, eloquence, forgiveness, global, humility, militancy, negotiator, stalwart and Kafkaesque. Elsewhere, Mandela is described as '... the epicenter of our time, ours in South Africa, and yours, wherever you are' (Gordimer in Smith 2014:ix) and as having '.. become part of the warp and weft of the chronicle of South Africa's negotiated transition from Apartheid to democracy' (Maharaj in Joffe 2007:xix), someone who has left the world an 'imperishable legacy' (Carlin 2013:xiii). On and on they go - these words of praise for Mandela, words which, though intended for praise, carry with them the seeds of the 'burial' of his personality. For surely, no mortal human can withstand such a 'total onslaught' of layer upon layer of praise and hyperbole.

At what point does admiration drift into caricature - intended of unintended? Is it when the admirers begin to compete for the most memorable phrase of praise? Is it when the object of praise becomes an unspoken allocator of prestige in the very act of praise? Is it when the admirers use the admired as a camouflage for self-admiration?

How does it happen - outside the world of religious worshipthat one man or woman amongst a set of equally deserving peers is singled out for the most lavish praise human words can give? Has the world drifted unwittingly into the realm of religion when it comes to Nelson Mandela? I suppose this occurs when a man or a woman comes to represent and symbolise, as evocatively as possible, the past, the present and the future of a people as well as the world they wish to have. Ostensibly, this is what Nelson Mandela has come to represent. There are other explanations for the Mandela exception. Former South African President Thabo Mbeki offers an explanation of the 'personality cult' around Nelson Mandela. It was in the context of his letter to President Jacob Zuma in which he warned about the dangers of the ANC becoming 'enslaved in the cult of the individual'. Thabo Mbeki (2008) contends that:

\footnotetext{
... there were exceptional circumstances attached to Comrade Nelson Mandela, which were not of his making or will. In the context of the global struggle for the release of political prisoners in our country, our movement took a deliberate decision to profile Nelson Mandela as the representative personality of these prisoners, and therefore to use his personal political biography, including the persecution of his then wife, Winnie Mandela, dramatically to present to the world and the South African community the brutality of the apartheid system. ... However, for me personally, at no point did this translate into 'hero worship' and therefore the progression to the phenomenon of the 'cult of personality'.
}

The Mbeki explanation is plausible but cannot completely exhaust the matter. Surely even Mbeki and his fellow conspirators in their premeditated employment and deployment of the Mandela image for representivity must have been surprised - even if pleasantly so - at the success of their 'experiment'! There must have been something about Nelson Mandela's standing, qualities and conduct that enabled so many people to 'buy into' his image and name. Expressed differently, there must have been some 'demand' for a Mandela character to which the decision to 'profile Nelson Mandela as the representative personality of these prisoners' was providing some 'supply'.

Maybe the difference between Mandela and his comrades was not so much of substance but rather a difference in performance ability - a telling difference all the same. None of the other comrades had for a wife as formidable a personality as Winnie Madikizela-Mandela. This is despite the fact that, lately, she is systematically being written out of Mandela iconology - except as some sort of villainous character.

In the first instance, the problem is not so much whether what people say about Mandela is correct, incorrect or exaggerated. It is after all how they see and experience him, and no one can take that away from them. The problem is 
one of an emerging single story of triumph and sainthood of the post-1990 Nelson Mandela. What is emerging is one powerful meta-narrative of a gigantic personality that stood as tall as the '... soulless, truly horrendous sculpture that dominates Mandela Square in Sandton' (Soyinka 2004:33).

We started off by asking if Mandela can withstand the onslaught, but the real question is whether we can withstand the onslaught of so huge, so soulless and so perfect a picture of Mandela. If Mandela is a giant whose shoulders touch the skies, as in the Sandton Square statue, what does that make of his comrades and the rest of humanity under his dancing gaze?

Soyinka (2004) notes nonchalantly, if not also hastily, that there are many other

\begin{abstract}
... figurative representations of Madiba that I have seen, from the naive to the sophisticated - all inspired by love, veneration, fantasy, canonization, wish-fulfilment, etc. to even the fetishistic executions in paint, clay, in arrangement beads and cowrie shells and other durable material on cloth, raffia, sculpted in wood and bronze ... (p. 33)
\end{abstract}

The problem is that many of these representations of Mandela may 'praise him to death'. The challenge we must face squarely is how to rescue Mandela from the clutches of deathly adoration. How can we save ourselves from being pummelled down by an image of Mandela in light of which we all fade into grey? How do we wrest Mandela from the chokehold of global praise? before he shouts his last 'I can't breathe' like the New York street vendor, Eric Garner?

How do we find, from amongst the many representations of Nelson Mandela, the more human and more realistic? And if there are none to be found, how can we invent a more human and more soulful representation of Nelson Mandela? How can we craft more critical appraisals of Nelson Mandela?

Rescuing Nelson Mandela from the global adoration chokehold is the first lesson in the meaning of Nelson Mandela. For unless we succeed, the meaning of a Mandela who ran the planes of Xunu, who walked the dangerous streets of Alexandra, who was forced to strip naked in prison and told by Colonel Piet Badenhorst at Robben Island to 'pull your finger out of your arse' (Mandela 1994:544) will be lost to us forever.

We must be wary of the hasty move from Mandela the ordinary to Mandela the leader. Rather than focus exclusively on the post-1990 Mandela magic, let us probe the pre-1980 Mandela magic - the magic that made him an 'armed and dangerous terrorist'. Let us probe the magic of his frequently confessed inner sense of inadequacy even as we seek to learn from the magic of his bravery. We owe it to ourselves to look into the eyes not of the dancing Nelson Mandela of the 1990s but of the Mandela of the 1950s, 1960s, 1970s and 1980s.
Unless we can find or invent more Mandela narratives than the current hegemonic one, we are in danger of 'killing' Mandela and of dying with him in the process. We must therefore find a crack in the shiny cement floors and overcrowded goldplated walls of the Mandela worship house.

If Mandela is the Shakurian rose that grew through a crack in the concrete of Apartheid, the time has come for a hundred new roses of alternative Mandela narratives to sprout through the cracks of a cemented Mandela worship floor.

And yes, there are cracks on this narrative floor of concrete pretensions. Consider Mandela's almost condescending anger against the PAC which led to him reserving some of his harshest words for it. Consider his anger - often disguised towards two significant women in his life - Winnie and Evelyn. Consider how he once lost his temper to the point of a near fist-fight against at least two prison warders. Consider his inner sense of inadequacy and inner need for absolute loyalty. Consider his sense of guilt and shame for shirking (his own word) his responsibility to his aging mother.

\section{The need for a perfect Nelson Mandela}

Perhaps the biggest crack of all is to be found in our own abnormal need for a giant Mandela - moral giant, leadership giant, character giant. This is our problem and not Mandela's.

Chinua Achebe (1983:9) once remarked about the inordinate Nigerian hunger for greatness, often expressed both by Nigerian leaders and ordinary people alike. He contrasted the words of former West-German Chancellor Helmut Schmidt who said in 1979, 'Germany is not a world power; it does not wish to be a world power' to those of General Olusegun Obasanjo who said in Ogun State in the same year that 'Nigeria will become one of ten leading nations in the world by the end of the century'. Is it not ironic that the continent and the people who produced 'the last pure hero on the planet' are also the most wretched on the face of the earth? Is there a connection between our wretchedness and our need for a big and pure Mandela figure?

Could the global adoration for Nelson Mandela be cynical and ultimately utilitarian? After all, world adoration of Mandela has not necessarily shifted the world's perception of Africa and Africans, or has it?. During his 'foreign inaugural speech' (Soyinka 2012:171) delivered in Accra, Obama (2009), who has been said to be '... a worthy heir to Mandela' (Boehemer 2014:161), generally spoke respectfully to his primary audience - the Muslim world - although in hindsight some Muslims will disagree. In contrast, when Obama (2009) gave his 'African Inaugural speech' in Accra Ghana, there were many moments when one felt he was finger-wagging and 'talking down'. Amongst other things, he said:

But if we are honest, for far too many Africans, conflict is a part of life, as constant as the sun. There are wars over land and 
wars over resources. And it is still far too easy for those without conscience to manipulate whole communities into fighting among faiths and tribes. These conflicts are a millstone around Africa's neck. Now, we all have many identities - of tribe and ethnicity; of religion and nationality. But defining oneself in opposition to someone who belongs to a different tribe, or who worships a different prophet, has no place in the 21st century.

It is possible that we leech on Mandela's name in a desperate attempt to rid ourselves of centuries of the contemptuous gaze in which the so-called developed word has held Africa. In joining in the veneration of Mandela, the so-called developed world, apart from making whatever money and mileage can be made on the name of Mandela, may be subtly pressuring us into further submission, indirectly demanding of all Africa and Africans to be as forgiving and as reconciliatory as Mandela. Mandela exceptionalism, to the extent that it exists, may be one more prism through which to look down upon wretched Africans with pity.

During November 2009 in Bayreuth, Germany, after giving a lecture, Wole Soyinka (2012) was stunned when a young man confronted him with the unnerving certainty of a 'deeply embraced credo', saying:

Africans, you must admit, are inherently inferior. You must be, or other races would not have enslaved you for centuries. Your enslavers saw you for what you were, so you cannot blame them. (p. xii)

Soyinka (2012) noted that the sentiment in this statement was not just

... one voice but many, from across Europe and other continents. Usually suppressed, it nonetheless only awaited a chance to burst forth - and not only in abrasive words across a dinner table, but in organized bouts of xenophobic violence (p. xii)

Do you think the young man who confronted Soyinka knows of Nelson Mandela? Sure he does. Do you suppose he might think Nelson Mandela is one of the greatest leaders in the 20th century? Sure he does. Does he think Nelson Mandela is representative of Africa and Africans? Sure you wish. Nelson Mandela has become the exception that proves the rule.

\section{Other dimensions to Nelson Mandela}

Mandela's autobiography has several anecdotes and reflections that communicate and testify to inadequacies and weaknesses either in behaviour or character. Some are clearly designed by him to communicate weaknesses whilst others are not necessarily intended as such. Indeed some weaknesses are strengths and vice versa. I propose below eleven possible caveats and leads that could be explored as we search for a more human Mandela in between the cracks of the concrete of a dominant Mandela grand narrative.

\section{Mandela had feelings of inadequacy?}

In his biography, Mandela is at pains to prove that he had an ordinary rural upbringing, albeit somewhat privileged owing to him being adopted by the regent Jongintaba. The young Mandela did all the naughty things like stealing corn from his adoptive family and together with his friends stealing and slaughtering a pig on the spot. Mandela was also unsure of himself amongst the more sophisticated and particularly around women. His love for Rev Matyolo's daughter at the Great Place was disastrous as he suffered from severe feelings of inadequacy and an inability to fit into the more Westernised life-style of the Matyolos. He could not, for example, use a fork and knife but chose to pretend, disastrously, that he could (Mandela 1994:28). He struggled to walk on the first day he ever wore boots (Mandela 1994:39). While living in Alexandra, Mandela fell in love with a girl called Didi Xhoma, a member of the family from whom he rented a room, but he never once plucked up the courage to tell her. 'I yearned to tell Didi I loved her, but I was afraid that my advances would be unwanted' (Mandela 1994:95)

\section{Making fun of Mandela}

One feels a diffidence even amongst the comedians and the creative satirists to 'make fun' of Mandela beyond the overdone if also easy imitation of his voice. For this reason, celebrated South African comedian Trevor Noah's (2010) parody of a drunk Mandela celebrating his 91st birthday is in part hilarious because it is a rare comedic engagement with Mandela. It is based on the outrageous suggestion that to celebrate his 91st, Mandela decides to 'get wasted', as in very drunk. Of course, Mandela did not take alcohol, but that is the nub of the skit. Noah starts by noting how Mandela is treated so much like a saint that he is not even allowed to fart like other human beings. So in his imagined 'drunken stupor', Mandela embarrasses several luminaries, starting with his own wife Graça Machel whom he accuses of not knowing who Mandela really is. Next he summons Bill Clinton who is in attendance to embarrass him about the transparency of his denial of the Monica Lewinsky sex scandal. Then Mandela spots Julius. Accusing him of having a loud mouth, he proceeds to ask Julius a simple arithmetic question to which Julius responds enthusiastically but predictably wrongly. The skit ends with Mandela proposing a toast whose basic message is to encourage everyone to get drunk. During the toast, a drunk Nelson Mandela gloats over the fact that he outlived Michael Jackson. To celebrate his 'victory' over Michael Jackson he does a classic Michael Jackson hip swing followed by Michael's famous crotch grab with Mandela rhetorically asking, 'Who's bad now?'

In prison, Mandela did meet fellow prisoners who disagreed with him vehemently, such as Neville Alexander and Govan Mbeki. One particular person, however, made it his business not to just confront but to deride both Sobukwe and Mandela with biting sarcasm. That man was Stephen Tefu, a communist and a member of the PAC. Mandela (1994:399) describes Tefu as, 'dyspeptic, argumentative, overbearing ... also articulate [and] knowledgeable ...' In another reference, Mandela (1994) refers to Tefu as follows:

Ah, said Tefu with disgust, 'Mandela is a little boy who is afraid of the white man. I don't even know who he is. One 
morning, I woke up and found every newspaper saying, "Mandela, Mandela, Mandela", and I said to myself, "Who is this Mandela?" I will tell you who Mandela is. He is a chap built up by you people for some reason that I don't understand. That is who Mandela is.' (p. 399)

\section{Mandela the believer}

Mandela was a member of the Student Christian Movement. As a student at the University of Fort Hare, Mandela taught Bible classes on Sundays together with the young Oliver Tambo. Once while in Cape Town visiting with Reverend Teka, a Methodist pastor and ANC activist, Mandela tells of how '... led by him, we knelt down in prayer for the well-being of those whose homes had been raided' (Mandela 1994:220). Elsewhere Mandela confesses that '... at Mqhekezweni religion was part of the fabric of life and I attended church each Sunday along with the Regent and his wife' (Mandela 1994:23) so that the chieftaincy and the church absorbed him completely, as indicated in the following quote:

The two principles that governed my life at Mqhekezweni were chieftaincy and the Church. These two doctrines existed in uneasy harmony, although I did not then see them as antagonistic ... But the church was as concerned with this world as the next. I saw that virtually all of the achievements of Africans seemed to have come about through the missionary work of the church. (Mandela 1994:23)

Though many of his biographers tend to downplay the influence of religion on Mandela, both Christian and African, he himself does not.

\section{Mandela, jobs and money}

His first job was as a night-watchman at a mine. In one section of his biography, Mandela shares his monthly budget (Mandela 1994:89) and how he was left with a negative balance each month. Mandela (1994) recalls how, one day, Hans Muller, a white estate agent, pulled him to the window and said:

Look out there, Nelson, he said. 'Do you see those men and women scurrying up and down the street? What is it they are pursuing? What is it they are working for so feverishly? I'll tell you: All of them, without exception, are after wealth and money. Because wealth and money equal happiness. That is what you must struggle for: money and nothing but money. Once you have enough cash, there is nothing else you will want in life. (p. 100)

It does not seem as if Mandela ever gave in to the temptation of letting money define him, but he suffered from frequent pangs of guilt for failing to provide for his family.

\section{Mandela, intelligence and wisdom}

While Mandela's stint as a student at WITS opened '... a world of ideas and political beliefs and debates, a world where people were passionate about politics' (Mandela 1994:105), he also admits that '... my performance as a law student was dismal' (Mandela 1994:104). Was this false humility or honest truth telling? Of course, Mandela was not unintelligent. He could not otherwise have become the brilliant lawyer and leader that he was. But by his own admission, he was neither the fastest or brightest student in class. His biographers have noted that he was disciplined, methodical and persistent. This, more than intelligence of the exclusively cerebral type, seems to have contributed to his success. Mandela was clearly a very wise man.

\section{Mandela had no Damascus road experience}

It is instructive that, although many have suggested particular events and moments which either politicised Mandela or helped him maintain his political consciousness, he himself suggests the following:

[I] had no epiphany, no singular revelation, no moment of truth, but a steady accumulation of a thousand slights, a thousand indignities and a thousand unremembered moments [which] produced in me an anger, a rebelliousness, a desire to fight the system that imprisoned my people. (Mandela 1994:109)

Not once in his biography or his Conversations with myself does Mandela mention the poem Invictus by William Ernest Henly that is supposed to have been his mantra and constant inspiration. However, an event that came close to an epiphany was the impact of a speech delivered by Chief Meligqili at Mandela's home-coming ceremony after his circumcision. Amongst other things, the Chief said:

\begin{abstract}
Among these young men are chiefs who will never rule because we have no power to govern ourselves; soldiers who will never fight for we have no weapons to fight with; scholars who will never teach because we have no place for them to study. The abilities, the intelligence, the promise of these young men will be squandered in their attempt to eke out a living doing the simplest, most mindless chores for the white man. These gifts today are naught, for we cannot give them the greatest gift of all, which is freedom and independence. (Mandela 1994:35)
\end{abstract}

\section{The Mandela of sorrow, guilt and shame}

One notices the brevity and stoicism with which Mandela discusses personal loss and pain. 'When she was nine months old, Makaziwe passed away' (Mandela 1994:122), he says briefly before switching back to ANCYL politics. Similarly, he recalls how his oldest son, Thembi, then five, who hardly saw his father owing to his political activism, once asked his mother: 'Where does Daddy live'? His two-year old daughter once woke up late at night upon hearing her daddy preparing to leave on yet another clandestine trip and asked if she could go with him (Mandela 1994:207). More painfully, his children once had to watch him being arrested. 'It is not pleasant to be arrested in front of one's children, even though one knows that what one is doing is right' (Mandela 1994:233). When Mandela divorced Evelyn, the children were traumatised:

Makgatho took to sleeping in my bed. He was a gentle child, a natural peacemaker, and he tried to bring some sort of reconciliation between me and his mother. Makaziwe was still very small and I remember one day, when I was not in prison or in court, I visited her crèche unannounced. She had always been a very affectionate child but that day when she saw me, she 
froze. She did not know whether to run to me or retreat, to smile or frown. She had some conflict in her small heart, which she did not know how to resolve. It was very painful. Thembi, who was ten at the time ... stopped studying and became withdrawn. (Mandela 1994:242)

However, it was the death of his mother and his son Thembi which left Mandela gutted:

What can one say about such a tragedy? I was already overwrought about my wife, I was still grieving for my mother, and then to hear such news. I do not have words to express the sorrow, or the loss I felt. It left a hole in my heart that can never be filled. (Mandela 1994:531)

Mandela's (1994) guilt over neglecting his family found fuller expression once while visiting his aging mother before she died:

Although I was happy to be back, I felt a sense of guilt at the sight of her living all alone in such poor circumstances. I tried to persuade her to come and live with me in Johannesburg but she swore that she would not leave the countryside she loved. I wondered - not for the first time - whether one was ever justified in neglecting the welfare of one's own family in order to fight for the welfare of others. Can there be anything more important than looking after one's own aging mother? Is politics merely a pretext for shirking one's responsibilities, an excuse for not being able to provide in the way one wanted? (p. 212)

He expressed the same anguish when Winnie was in prison and rumours of her torture abounded:

Nothing tested my equilibrium as the time when Winnie was in solitary confinement ... I had sleepless nights. What were the authorities doing to my wife? How would she bear up? Who was looking after our daughters? Who would pay the bills? (Mandela 1994:530)

\section{Mandela the political boxer}

Beyond the fact that he was an amateur boxer, boxing seems to have been an important political metaphor for Mandela (1994):

I was never an outstanding boxer. I had neither enough power to compensate for my lack of speed nor enough speed to make up for my lack of power. I do not enjoy the violence of boxing as much as the science of it. I was intrigued by how one moved one's body to protect oneself, how one used a strategy both to attack and retreat, how one paced oneself over a match. Boxing is egalitarian. In the ring, rank, age, colour and wealth are irrelevant. When you are circling your opponent, probing his strengths and weaknesses, you are not thinking about his colour or social status. (pp. 225-226)

Perhaps he transformed his defensive 'boxing skills' into humour in the face of utter humiliation:

Upon admission [to prison] we were taken to an outdoor quadrangle and ordered to strip completely and line up against the wall. We were forced to stand for more than an hour, shivering in the breeze and feeling awkward - priests, professors, doctors, lawyers, businessmen, men of middle or old age ... Despite my anger I could not suppress a laugh as I scrutinized the men around me ... If fine bodies and impressive physiques were essential to being a leader, ... few among us would have qualified. (Mandela 1994:233)

\section{An angry Mandela}

In his biography, Mandela admits to many emotions, especially love. Seldom does he allow his anger to come through. The section dealing with the PAC (Mandela 1994:266ff.) is a clear exception. The organization is described as engaging in immature, opportunistic and naive behaviour ahead of the Sharpeville massacre and of adopting '... an over-ambitious programme that promised quick solutions'. Elsewhere the PAC is described as '... lost, they were a leadership in search of followers' (Mandela 1994:279). His anger also showed whenever some warder abused his dignity and that of Winnie. Once a warder '... uttered something so offensive and uncomplimentary about my wife that I immediately lost my temper. I rose from my chair and started to move around the desk towards him' (Mandela 1994:562). During the CODESA negotiations, we saw a glimpse of the angry Mandela (1991) giving FW de Klerk a severe tonguelashing. We also catch a glimpse of the Mandela anger in his disagreements with Evelyn in the lead up to the divorce. What happened to that well of anger that built up in him all those years in jail? Could the alleged exclusion of MadikizelaMandela from his final will be an aspect of this anger? The tough question to ask of Mandela therefore is not whether he has forgiven his jailors but whether he managed to forgive his former wife.

\section{Mandela and subversive clothing}

Some have noted that Mandela loved clothes, but it was for reasons other than glamour. He understood the power of symbolism and impression. When he wore the leopard skin karos in court in October 1962, Mandela wanted to make an impact on the crowd and the court officials. The karos was meant to 'electrify' the crowd, and it did. It was meant to symbolise that 'I was a black man walking into a white man's court' (Mandela 1994:385). It was meant to demonstrate that 'I was literally carrying on my back the history, culture and heritage of my people'. It was an 'embodiment of African nationalism' and a 'sign of contempt for the niceties of white justice' (Mandela 1994:385). Perhaps the so-called Madiba shirt was not so innocent.

\section{Mandela losing it in jail?}

Jail was tough on Mandela. 'Prison not only robs you of your freedom, it attempts to take away your identity. Everyone wears a uniform, eats the same food, follows the same schedule' (Mandela 1994:396). Once, when Mandela protested about clothes and food, he was given a choice between those and solitary confinement. He chose the latter, something he would regret later:

For the next few weeks I was completely and utterly isolated. I did not see the face or hear the voice of another prisoner. I was locked up for twenty three hours a day, with thirty minutes 
of exercise in the morning and again in the afternoon. ... every hour seems like a year. There was no natural light in my cell; a single bulb burned overhead twenty-four hours a day. I did not have a wristwatch and I often thought it was the middle of the night when it was only late afternoon. I had nothing to read, nothing to write on or with, no-one to talk to. The mind begins to turn on itself ... after a time in solitary, I relished the company even of insects in my cell, and found myself on the verge of initiating conversations with a cockroach. (Mandela 1994:397)

In jail, Mandela and his comrades were treated like animals, sometimes in the most trivial of ways:

The warder had an extra sandwich and he threw it on the grass near us and said to us, 'here'. .. This presented us with a dilemma. On the one hand, he was treating us as animals to whom he could toss a bit of slop ... On the other hand, we were hungry ... (Mandela 1994:498)

\section{Conclusion}

If the triumphalist Mandela grand narrative is not to choke him and us to death, we must disrupt, deflect and ward it off with all the tactics and strategies available to us. Mandela was a great leader because he was an ordinary human being, very conscious of his weaknesses. We neglect his weaknesses at our own peril. In fact, to neglect his weaknesses is to refuse to learn from him.

The post-1990 Mandela seems to have taken over all of Mandela. The pre-1990 Mandela is in danger of being totally romanticised. It is as if Mandela's life started in February 1990. This tendency is graphically displayed in Nicol (2013). Although the book has the sub title of 19182013, the first chapter of the book, titled 'the making of a leader' starts as follows (Nicol 2013:11): 'On a hot Sunday afternoon, 11 February 1990, Nelson Mandela walked out of Victor Verster prison, in the Cape winelands, a free man ...'

To remedy this situation, we shall need to go beyond the 'how to' Mandela books (how to lead like Mandela, how to think like Mandela, et cetera). These books are looking for the sanitised and easy lessons from Mandela. Few of these books, if any, suggest that, to lead like Mandela, one must abandon one's mother, children and wife. Few of these books says that, to think like Mandela, one may have to be disparaging even of progressive political opponents such as the PAC. Few of these books say that, to lead like Mandela, you must spend 21 years without so much as touching your own wife. None of these books says that, to think like Mandela, you must be able to have conversations with ants and make friends with cockroaches in a solitary cell equipped with an ever burning bulb and a toilet hole.

We need to shove aside the countless mountains of superlatives under which Mandela is being buried. We must be vigilant and weary of the sanitised Mandela quotation books, designed for the sound-bites and speech making. We will have to meet the inadequate Mandela, the angry Mandela, the ashamed Mandela and the political boxer who may have lost his most important fights inside his own homestead. The question is: Do we wish to learn from Mandela, or do we wish to bolster our wretched self-esteem and worship our own selves through him?

\section{Acknowledgements Competing interests}

The author declares that he has no financial or personal relationships which may have inappropriately influenced him in writing this article.

\section{References}

Achebe, C., 1983, The trouble with Nigeria, Heinemann, Oxford.

Boehemer, E., 2014, 'Nelson Mandela: The oratory of the Black Pimpernel', in A. Adekeye (ed.), Africa's peacemakers: Nobel peace laureates of African descent, pp. 161-177, Zed books, Cape Town.

Brutus, D., 2011, 'Robben Island', in B. Lindfors (ed.), The Dennis Brutus tapes: Essays and autobiography, pp. 92-109, James Curry, Woodbridge.

Carlin, J., 2013, Knowing Mandela, Atlantic Books, London.

Joffe, J., 2007, The State vs. Nelson Mandela: The trial that changed South Africa, One World, London.

Mandela, N., 1991, 'Response by Nelson Mandela to FW De Klerk's opening statement' viewed 04 March 2015, from http://www.anc.org.za/show.php?id=3977

Mandela, N., 1994, Long walk to prison, Abacus, London.

Mandela, N., 2002, Madiba magic: Nelson Mandela's favorite African folktales, Norton and Company, New York, NY.

Mbeki, T., 2008, 'Letter to President of the ANC', IOL News, viewed 01 March 2015 , from http://www.iol.co.za/news/politics/mbeki-s-letter-to-the-anc-1.422603\#. VbdaYUs6Hwl

Nicol, M., 2013, Mandela: Celebrating the legacy, Pearson, Cape Town.

Noah, T., 2010, Daywalker, DVD, Podium \& Numetro, Johannesburg.

Obama, B., 2009, 'Speech delivered at the Ghanain parliament', viewed 04 March 2015, from http://www.whitehouse.gov/the_press_office/Remarks-by-thePresident-at-Cairo-University-6-04-09

Sampson, A., 1999, Mandela: The authorized biography, Harper Collins, London.

Schechter, D., 2013, Madiba A to Z: The many faces of Nelson Mandela, Jacana, Sunnyside.

Shakur, T., 2006, The rose that grew from concrete, Simon \& Schuster, London.

Smith, D., 2014, How to think like Mandela, Michael O'Mara, London.

Soyinka, W., 1988, Mandela's earth and other poems, Random House, New York, NY.

Soyinka, W., 2004, 'Views from a palette of the cultural rainbow', in X. Mangcu (ed.), The meaning of Mandela: A literary and intellectual celebration, pp. 24-40, HSRC, Pretoria.

Soyinka, W., 2012, Of Africa, Yale University, New Haven, CT.

Stengel, R., 2010, Nelson Mandela 1918-2013: Portrait of an extraordinary man, Virgin, London.

West, C., 2004, 'Nelson Mandela: Grand exemplar of the grand democratic tradition', in $\mathrm{X}$. Mangcu (ed.), The meaning of Mandela: A literary and intellectual celebration, pp. 13-23, HSRC, Pretoria. 